\title{
Contribution of Leasehold Forests in Reducing Income Inequality
}

\author{
Bishnu Prasad Sharma, PhD*
}

\begin{abstract}
Structural transformation in the economy and institutional innovations bring changes in the socio--economic dynamics in the society. This leads to changes in the pattern of income distribution, poverty and income inequality. Environmental resources such as forest still make significant contribution in rural household economy. The leasehold forestry program for the poor introduced in the last decade of 2000 with the purpose of forest regeneration and raising household income in Nepal has completed more than two decades. Using micro data collected at household level from two districts in Nepal in 2008, this paper examined the contribution of leasehold forest and other sources in household economy. The study finding revealed that all biomass income sources including agriculture and wage work had income inequality reducing effects measured in terms of Gini-coefficient. In contrast, remittance and salary and business income had inequality raising effects. As leasehold forest contributed less than 5 percent of the household income even after 10 years of investment, there is a strong need to improve its performance by integrating it with income generating activities such as livestock and agroforestry. The inequality raising effect ranging from 3 to 6 percent from various biomass sources needs to be better utilized.
\end{abstract}

Key words: leasehold forestry, household income, income inequality, inequality reduction

\section{INTRODUCTION}

Structural changes in the economy arising from internal and external factors have significant impact on the sources of income and its distribution (UNRISD, 2010). In a changing world, traditional sources give up to more recent sources, bringing changes in income dynamics. New institutional innovations particularly in the field of natural resource management can have different distributional effects compared to the customary resource management regimes (Agrawal, 2007; Sunam \& McCarthy, 2010). In this regards, policy makers are interested in examining incomes at the household level from various source to provide information on how important the targeted income source is with respect to total income; how equally or unequally distributed the income source is; and how the income source and the distribution of total income are correlated. Traditional sources of income such as agriculture and wage earning are accessible to most of the population while business and salary income may be available

* Dr. Sharma is Associate Professor of Economics, Patan Multiple Campus, Tribhuvan University, Nepal 
to a limited proportion of the population with better skills and access to modern technology. Likewise access to remittance income may be skewed more towards high and middle income group rather than very low income group (Nepal \& Bohara, 2010). Environmental income, particularly through recent institutional innovations in the forestry sector such as community forestry or leasehold forestry are of interest from their potential in raising household income and reducing rural poverty and inequality. This paper analyzes the contribution of the forestry sector with focus on leasehold forest management on household income, the distributional equity and its correlation to total income. Leasehold forests (LHF) are new forms of property right management over forest resources introduced in Nepal in the decades of 2000 in which degraded forest lands were handed over to groups of identified poor households for a period of 40 years with provision of further extension, by the government (MFSC/HMG, 2002). LHF serve two purposes simultaneously- forest regeneration and raising household income.

The paper is scheduled as follow: the ensuing section discusses available literature on the issue, this section is followed by the methodology used in the paper, and the second last section presents the main findings.The final section concludes with some discussions on the limitations of the methods, comparability with other studies and policy implications of the findings.

\section{LITERATURE REVIEW}

A number of studies have been undertaken to identify the income equalizing effects by various sources. For instance Babulo et al. (2009) examined the case for forest environmental sources. Their analysis revealed that in agrarian economies forest income contributed as the second largest share in total household income following crop income. Incorporating forest environmental incomes also significantly reduced measured rural poverty and income inequality. A study in rural Nepal by Joshi et al. (2008) in Gulmi district of western Nepal indicated that labour intensive agriculture can have income equalizing effect in contrast to salaried job and remittance. A micro level estimation and decomposition of poverty and inequality (Nepal \& Bohara, 2010) using the living standard survey data for 1995/96 and 2003/04 indicated that enterprise income, rental income and remittance were the highest contributor to income inequality while agriculture and wage income contributed to reduce it the most. In this regards, the analysis of inequality decomposition and the marginal effects the most widely accessible natural resource such as forests from the private and public ownership aspect is lacking. This is particularly true for relatively newly introduced and targeted forestry program such as the leasehold forestry. 


\section{METHODOLOGY}

This section provides a brief description of the area where the study was conducted, the sampling design, methods of data collection and the tools of analysis used in the study. The method of economic valuation of non-market forest products and method of decomposing inequality measure is discussed in this section.

\section{Study Area}

The study area for the present paper is Kavre and Makwanpur districts. The two districts were purposively selected based on their status as pioneering districts of leasehold forestry (LHF) in Nepal. Both the districts fall in the mid-hills region of Nepal in which large part of the forest areas had been degraded due to several reasons such as open grazing, unsustainable harvesting and most importantly, the lack of effective property right regime over the resource for sustainable management. Leasehold forestry started initially somewhat as a piloting project under Hills Leasehold Forestry and Forage Development Project later institutionalized under the Forest Act 2093 and Forest Regulations 1995. Due to their focus on the poor households, leasehold forestry is a priority program of the government of Nepal.

\section{Sampling and Data}

The data for the present analysis comes from primary data collected at the household level from Kavre and Makwanpur in 2008. Since LHF programme is based on the principle of natural regeneration of forest, five years was considered as a gestation period for forest regeneration to allow for harvesting based on discussion with forestry professionals. There were 245 and 194 LHF groups in the two districts with more than five years of tenure distributed in several Village Development Committees (VDCs). The VDC was the primary unit of sampling in the first stage; LHF group was the unit of selection in the second stage, and finally household was the final unit in the third stage. Probability proportional to size (PPS) sampling method was used for the selection of the VDCs. The final sampling outcome was selection of 10 VDCs in Makwanpur and 8 VDCs in Kavre. In the next stage, a simple random sampling was performed for the selection of LHF groups within the selected VDC and finally, a census of the all available households in the selected LHF group was conducted. The sample consisted of a total of 508 households.

Data was collected using structured interview schedule on household income from various sources such as farm income, wages, salaries, business, transfer income and other sources such as remittance, rental incomes etc. Data was also collected for forest products from various forest management regimes. Other data collected included household collection time from various forest sources. Local wage rate data and cost 
of other provision such as food, drinks, cigarette etc along with local working hours was also collected for estimating real hourly wage rate.

\section{Tools of Analysis}

Different tools were used for estimating household income from various sources. Household incomes from crops and livestock were estimated using prevailing market prices. Household income from crops was estimated from a list of all potential crops grown by household, their annual inputs and yields. Monthly Money incomes and number of months employed in a year were used to estimate income from wages and salaries and other sources such as business, remittance and transfer payments. A one year period prior to the survey was the basis of all data for income sources. In case of forest products collected, as no market existed for these products, alternative methods with household time was used for economic valuing of forest products. Household time of forest biomass collection with their several variants has been used by several earlier studies such as Hartter and Boston (2008), Kohlin and Amacher (2005), and Macdonald et al. (2001). We used a similar method for estimating value of forest biomass based on collection time. For this purpose, we estimated the mean value of the potential minimum and maximum wage rate. The minimum wage was equivalent to the cost of producing physical energy measured in terms of food consumed at prevailing local price to undertake the activity. The maximum wage was the prevailing agricultural wage rate. Wage rate for informal casual work were assumed to be settled at a mean of these two limits (for details see Sharma, 2011). The annualized value of timber was estimated by collecting information from the household on the expected present value of the standing trees and adjusted it with the number of years of operation. Households valued plots on the basis of the timber trees in their plots.

Once household incomes from all sources were estimated, the inequality decomposition method was used. The Gini-coefficient that measures Lerman and Yitzhaki (1985) total income inequality can be decomposed further to examine the relative contribution of each of the income components in total Gini coefficient and to find out which sources are relatively more responsible for the inequality. This paper follows the method provided by and adopted by several studies such as Babulo et al. (2009), and Nepal and Bohara (2010) to decompose Gini coefficient by sources of income. Accordingly, if we have $\mathrm{N}$ income units (households) indexed by $(\mathrm{n}=1,2,3, \ldots, N)$ and the total income of each income unit is a sum of $\mathrm{K}$ different sources, then

$$
\mathrm{G}=\mathrm{S}_{1} \mathrm{G}_{1} \mathrm{R}_{1}+\mathrm{S}_{2} \mathrm{G}_{2} \mathrm{R}_{2}+\mathrm{S}_{\mathrm{K}} \mathrm{G}_{\mathrm{K}} \mathrm{R}_{\mathrm{k}} \ldots \ldots \ldots \ldots \ldots \ldots \ldots
$$

Where $S_{K}=$ the share of the income component in total household income and is a measure of the importance of the income source $K$ in the total income. Likewise, $G_{K}$ is 
the Gini of the source of income $\mathrm{K}$ and is a measure of inequality of the distribution of source $K . R_{K}$ is the Gini correlation between income source $K$ with the cumulative distribution of the total income. The term $S_{K} G_{K} R_{K}$ is the contribution of the Kth income source to the overall income inequality.

Decomposing the total Gini to components allows examining how changes in income from a particular source affect the total income inequality. This is done technically by estimating the marginal effect of the source of income. In mathematical notation this is done by obtaining the partial derivative of overall Gini coefficient with percentage change in source income such that:

$$
\frac{S G}{S \varphi}=S_{K} G_{K} R_{K}-S_{K} G=S_{K}\left(G_{K} R_{K}-G\right) \cdots \cdots \cdots \cdots \cdots \cdots \cdots \cdots
$$

The relative marginal effect of source income $\mathrm{K}$ to the overall Gini can be obtained by dividing equation (2) by $\mathrm{G}$ produces

$$
\frac{\frac{\partial G}{\partial \varphi}}{G}=\frac{S_{K} G_{K} R_{K}-S_{K} G}{G}=\frac{S_{K} G_{K} R_{K}}{G}-S_{K}
$$

In the present context, we can estimate the share of LHF income in total income, share of inequality in LHF resources in overall Gini and to analyse whether a percentage increment in LHF income with raise or reduce overall inequality in income. Statistical software package Stata was used to obtain Gini decomposition using command "descogini".

\section{MAIN FINDINGS}

The average family size of the LHF households was 6.5.The average landholding size among LHF households was 0.6 hectares. For LHF households, community forests (at 52.6 percent) are the largest provider among the public land sources of firewood, followed by LHF (at 21.8 percent), government-owned forests (at 15.5 percent) and open access (at 10.1 percent). The tenure of the LHF regime for the sampled households varied between 6 to 13 years (with the mean at 10 years) as our study included in the sample only those LHF households with more than 5 years with a group due to the selection criteria employed. The mean area of LHF plots per household was 0.68 ha though the initial official target was to provide around one hectare per household.

For the valuation of the forest products, we devised an adjusted wage rate by averaging the calorific wage rate and the prevailing average local wage rate. The prevailing local real wage rate was obtained by combining the monetary wage rate and the in-kind wage served as food, drinks and smoking to the workers. While the prevailing average 
local real wage rate was Rs 13.4 per hour the calorific wage rate was Rs 0.98 per hour. The adjusted wage rate came to NRs 7.2 per hour on average for male and female labor. Using the time taken for local people to collect forest products from open access sources we estimate the average price per load of firewood, fodder-grass and leaf-litter to be NRs 11.63, 13.06 and 7.69 respectively. Using this value to estimate the value of forest products, we obtained the value of biomass from forest sources. For forest products which were marketable, we used the local market price.

The average income of the sampled LHF households was NRs. 87369 with a standard deviation of 82282 indicating high variance among households. The per capita income of the LHF households was NRs. 14089 (median= NRs. 10524; std dev. 12994).Crop income constituted almost a quarter share followed by some what equal share for salary and business income. Remittance income exceeded the local wage income. Livestock income was less than 10 percent. Total transfer income was slightly negative as there was a strong tradition of sending gift to relatives on occasions of death or other events. The major consituents of household income is summarised in Table 1.

Table 1: Components of Households Income

\begin{tabular}{lccc}
\hline \multicolumn{1}{c}{ Income components } & Mean (NRs) & Std. dev. & Percentage \\
\hline Crop income & 22812.7 & 31160.4 & 26.1 \\
Livestock income & 6895.5 & 18995.5 & 7.9 \\
Wage income & 9498.6 & 19025.5 & 10.9 \\
Salary and business & 22586.3 & 50562.9 & 25.9 \\
Remittance income & 10521.1 & 34221.1 & 12.0 \\
Transfer income & -22.4 & 9530.9 & -0.0 \\
Other income (interest, rent) & 1241.3 & 10118.1 & 1.4 \\
Household income without biomass income & 73533.2 & $\mathbf{8 1 1 2 8 . 2}$ & $\mathbf{8 4 . 2}$ \\
Biomass income from public source excluding LHF & 3591.8 & 3288.4 & 4.1 \\
Biomass income from LHF & 4104.1 & 4392.6 & 4.7 \\
Biomass income from private sources & 6140.3 & 4582.2 & 7.0 \\
Biomass income & $\mathbf{1 3 8 3 6 . 2}$ & $\mathbf{6 0 7 3 . 8}$ & $\mathbf{1 5 . 8}$ \\
Total household income & $\mathbf{8 7 3 6 9 . 4}$ & $\mathbf{8 2 2 8 2 . 8}$ & $\mathbf{1 0 0 . 0}$ \\
\hline
\end{tabular}

Source: Field Survey (2008).

Forest based income consitutued $16 \%$ and a slightly larger (56\%) chunk came from public land sources while a slightly smaller share $(44 \%)$ came from private land sources.The public forest other than LHF is mostly the community forest sources. The share of LHF biomass (flow of biomass and annualized value of timber stocks 
in plots) was around 5\% of household income. Among the public land sources, LHF contributed $53 \%$ while $47 \%$ came from community forest, government forest and open access soruces.The LHF thus was found to be a significantly large contributor in the household biomass income from non-private land sources of biomass.

Income accruing to the households from various sources sets up a pattern of distribution that can be considered equitable or inequitable. Table 2 summarizes the share of LHF income in total income, share of inequality in LHF resources in overall Gini and analyses whether a percentage increment in LHF income will raise or reduce overall inequality in income. Table 2 also reveals the Gini decomposition of various sources of income among LHF Households.

Table 2: Gini Decomposition by Income Source ${ }^{1}$

\begin{tabular}{lccccc}
\hline \multicolumn{1}{c}{ Source } & $\begin{array}{c}\text { Sk } \\
\text { (I) }\end{array}$ & $\begin{array}{c}\text { Gk } \\
\text { (II) }\end{array}$ & $\begin{array}{c}\text { Rk } \\
\text { (III) }\end{array}$ & $\begin{array}{c}\text { Share } \\
\text { (IV) }\end{array}$ & $\begin{array}{c}\text { Marginal } \\
\text { effect } \\
\text { (V) }\end{array}$ \\
\hline Crop income & 0.26 & 0.55 & 0.66 & 0.22 & -0.04 \\
Livestock income & 0.08 & 1.00 & 0.50 & 0.09 & 0.01 \\
Wage income & 0.11 & 0.77 & 0.30 & 0.06 & -0.05 \\
Salary and business & 0.26 & 0.80 & 0.75 & 0.36 & 0.11 \\
Remittance income & 0.12 & 0.92 & 0.76 & 0.20 & 0.08 \\
Transfer income & 0.00 & 0.00 & 0.11 & 0.01 & 0.01 \\
Other income (interest, rent) & 0.01 & 0.98 & 0.80 & 0.03 & 0.01 \\
Biomass income from other public & 0.04 & 0.48 & 0.07 & 0.00 & -0.04 \\
source excluding LHF & 0.05 & 0.54 & 0.27 & 0.02 & -0.03 \\
Biomass income from LHF & 0.07 & 0.39 & 0.18 & 0.01 & -0.06 \\
Biomass income from private sources & & 0.43 & & & \\
Total income & & & &
\end{tabular}

Source: Author's calculation.

The figures in column (I) indicate the respective share of various sources in aggregate income. Non-farm incomes (salary, business, remittance and others) constitutes the largest share (39 percent) followed by agriculture (26 percent). Remittance itself constitutes 12 percent while biomass income constitutes around 16 percent. Among

\footnotetext{
${ }^{1}$ Where Sk $=$ the share of the income component in total household income and is a measure of the importance of the income source $\mathrm{K}$ with respect to the total income. Likewise, Gk is the Gini of the source of income $\mathrm{K}$ and is a measure of inequality of the distribution of source K. Rk is the Gini correlation between income source K with the cumulative distribution of the total income. Share = the share of each income source in total inequality; Marginal effect $=$ the impact of a $1 \%$ change in the respective income source on inequality.
} 
various biomass sources, income from LHF constitutes around 5 percent while income from private biomass sources accounts about 7 percent and other public forest sources contribute around 4 percent.

The last row in column II is the Gini-coefficient of the total household incomes of LHF households and is equal to 0.43 and shows high economic disparity existing among LHF households. Regarding equality of distribution among each individual sources, agriculture incomes were distributed relatively less unequally (Gini of agriculture income is 0.55; Column II). Livestock incomes were most unequally distributed (1.00) followed by remittance (0.92). Incomes from LHF sources indicated disparity similar to agriculture in benefit sharing. Biomass income from private sources was relatively more equal. Column III is the Gini correlation between income source $\mathrm{K}$ with the cumulative distribution of the total income. The percentage contribution of individual sources in overall Gini as indicted by column IV indicated that highest contributor to income inequality was the non-farm income accruing from salary and business (0.36). The contribution of the agriculture sector in inequality was moderate. Around 2 percent of disparity in income measured in Gini-coefficient was created due to unequal accrual of benefits from LHF.

The marginal effects (column V) shows interesting result and have important policy implications. Increases in agricultural income and wage income have inequality reducing effects. The effects are quite strong as well. For instance, a one percent equal increase in income from agriculture to all households is expected to reduce income inequality by four and five percent respectively. Regarding forest sources, all forest incomes have inequality reducing effects ranging from 3 to 6 percent. Private sources have higher impact of 6 percent while other public sources and LHF has 4 and 3 percent effect on reducing income inequality. Thus, efforts to increase productivity in LHF and other biomass sources have important equality enhancing effect. Other sources such as non-farm incomes (salary, business and remittance etc.) have inequality raising effects. A one percent blanket increase in remittance incomes on the whole population is likely to exacerbate inequality expressed in terms of Gini coefficient by 8 percent.

\section{DISCUSSIONS AND CONCLUSIONS}

Poverty and inequality impacts are critical issues of a policy intervention. Various sources of income have differentiated impacts on poverty and income inequality and due to the nature of access among various sources among different strata of population; blanket policies of reducing income inequality through income enhancement from single sources may not be effective. 
The results have shown that the share of farm income has declined even among traditional farm and forest based communities. This result is somewhat consistent with the latest national household survey which estimated farm income around 32 percent for rural Nepal (CBS, 2011). Remittance income among sampled LHF households is slightly lower than national average of 18 percent. Forest based biomass income of the sampled LHF households still constitutes around 16 percent of household income.

Though crop income contributes only 26 percent, it contribution on income inequality is lower than salary and business. In this regards, ensuring equitable access and productivity of more equity creating sources is crucial for raising household income and reducing inequality. Traditional sources such as agriculture, wage working and forest product collection still have high income inequality reducing potential. Modern sources such as salary, business and remittance contribute a large share of about 38 percent but also exacerbate income inequality. This does not mean that these sources should be discouraged, but it indicates that more specific policies to improve access of the poor household such as targeted loans to poor household for financing to go abroad.

Regarding forest sources, LHF income with more than 10 years of involvement, less than 5 percent income accrue to households. Most of the forest management regimes are accused of being more oriented towards the interest of the relatively better-off communities. Instead of non-timber forest products, these communities emphasize on protection forest for timber harvesting in the future. This imposes cost and burden on the poor and the marginal groups as present consumption is much more important and these groups cannot wait so long. Policies and programs for more productively utilizing LHF land can contribute to greater income contribution of LHF on household income and consequently reduce income inequality in the community. Since all forest biomass sources show favourable marginal effects, integrating management of community forest and private waste land can have more multiplier effect when they are linked to rural income generation scheme through livestock, agro-forestry etc.

Acknowledgement: The author is thankful to South Asian Network for Development and Environmental Economics (SANDEE) for the support in the Study. Special thanks are due to E. Somanathan and Priya Shyamsundar for their guidance and feedback in this study.

\section{References}

Agrawal, A. (2007). Forests, governance, and sustainability: Common property theory and its contributions. International Journal of the Commons, 1(1), 111-136. 
Babulo, B., Muys, B., Nega, F., Tollens, E., Nyssen, J., Deckers, J. \& Mathijs, E. (2009). The economic contribution of forest resource use to rural livelihoods in Tigray, Northern Ethiopia. Forest Policy and Economics, 11, 109-117.

CBS.(2011). Nepal living standard survey 2011. Kathmandu: Central Bureau of Statistics, National Planning Commission Secretariat, Government of Nepal.

Hartter, J., \& Boston, K. (2008).Consuming fuel and fuelling consumption: Modeling human caloric demands and fuel-wood use. Small-Scale Forestry, 7 (1), 1-15.

Joshi, N. P., \& Maharjan, K. L. (2008). A study on rural poverty using inequality decomposition in western hills of Nepal: A case of Gulmi district. Journal of International Development and Cooperation, 14 (2), 1-17.

Kohlin, G., \& Amacher, G.S. (2005).Welfare implications of community forest plantations in developing countries: The Orissa social forestry project. American Journal of Agriculture Economics, 87, 855-869.

Lerman, R. I., \& Yitzhaki, S. (1985). Income inequality effects by income source: A new approach and applications to the United States. The review of economics and statistics, 151-156.

MacDonald, D.H., Adamowicz, W.L., \& Luckert, M.K. (2001). Fuel-wood collection in Northeastern Zimbabwe: Valuation and caloric expenditures. Journal of Forest Economics, 7(1), 29-51.

MFSC/HMG. (2002). Leasehold forest policy, 2002. Ministry of Forests and Soil Conservation. His Majesty's Government of Nepal.

Nepal, M., \& Bohara, A. (2010). Micro-level estimation and decomposition of poverty and inequality in Nepal. Himalayan Research Papers Archive.

Sharma, B. P. (2011). The welfare impacts of leasehold forestry in Nepal. South Asian Network for Development and Environmental Economics (SANDEE) SANDEE WP 6111.

Sunam, R. K., \& McCarthy, J. F. (2010).Advancing equity in community forestry: Recognition of the poor matters. International Forestry Review, 12, 370-382.

UNRISD. (2010). Combating poverty and inequality. UNRISD flagship report. United Nations Research Institute for Social Development 